\title{
PENGARUH MODEL PEMBELAJARAN MIND MAPPING TERHADAP HASIL BELAJAR MATEMATIKA SISWA
}

Anastasia Marxy

SMK Ksatria Bangsa

\begin{tabular}{l} 
INFO ARTICLES \\
\hline Article History: \\
Received: $11-01-2017$ \\
Revised: 18-01-2017 \\
Approved: $25-01-2017$ \\
Publish Online: $29-01-2017$ \\
\hline
\end{tabular}

Key Words:

Mind mapping learning, Student's mathematics achievement.

\section{cc) (7) (2)} ShareAlike 4.0 International License.

\begin{abstract}
The Impacts of Mind Mapping Learning Method on Student's Mathematics Achievement. The purpose of this research is to determine The Impacts of Mind Mapping Learning Method on Student's Mathematics Achievement at SMP Yasdiqin Citeurup raya street Bekasi, Rt $02 \mathrm{Rw} 05$ empirically. The method used in the research is experiment, sampling technique is random sampling. The instrument for data collection is multiple choice test consist of 25 items and the data was validated empirically. Data analysis technique is t test, and based on t test, $t$ test is 3.15 and table is 1.70 at significance level of $5 \%$. It means $t$ test $>t$ table $(3.15>1.70)$, it can be concluded that the average of student's Mathematics achievement through mind mapping learning method is more than cooperative learning type STAD on student's mathematics achievement.
\end{abstract}

\begin{abstract}
Abstrak: Tujuan dari penelitian adalah secara empiris mengetahui pengaruh model pembelajaran mind mapping terhadap hasil belajar matematika siswa kelas VII di SMP YASDIQ yang beralamat di Jln. Raya Citeureup Bekasi RT.02 RW.5. Metode penelitian yang digunakan dalam penelitian ini adalah metode eksperimen. Pengambilan sampel menggunakan teknik simple random sampling. Instrumen untuk mengumpulkan data pada penelitian berupa tes pilihan ganda yang terdiri dari 25 butir soal yang sudah divalidasi secara empiris. Teknik analisis data yang digunakan adalah uji $t$, dan berdasarkan perhitungan uji $t$ menunjukkan nilai $t_{\text {hitung }}=3,15$ dan $t_{\text {tabel }}=1,70$ pada taraf signifikansi $5 \%$, hal ini berarti $t_{\text {hitung }}>t_{\text {tabel }}$ yaitu 3,15 $>1,70$. Sehingga dapat disimpulkan bahwa rata-rata hasil belajar matematika siswa yang diberi perlakuan berupa model pembelajaran mind mapping lebih tinggi daripada ratarata hasil belajar matematika siswa yang diberi perlakuan berupa model pembelajaran kooperatif tipe $S T A D$. Dengan demikian, dapat disimpulkan bahwa model pembelajaran mind mapping berpengaruh signifikan terhadap hasil belajar matematika.
\end{abstract}

\footnotetext{
Correspondence Address: Jln. Raya Tajur Lewibidik, Tajur, Citeureup, Bogor, Jawa Barat, 16810, Indonesia; e-mail: anastasiamarxy7@gmai.com

How to Cite (APA $6^{\text {th }}$ Style): Marxy, A. (2017). Pengaruh Model Pembelajaran Mind Mapping Terhadap Hasil Belajar Matematika Siswa. JKPM (Jurnal Kajian Pendidikan Matematika), Vol 02 (02), 173-182. DOI: 10.1007/XXXXXX-XX-0000-00
}

Copyright: Marxy, A. (2017)

Competing Interests Disclosures: The authors declare that they have no significant competing financial, professional or personal interests that might have influenced the performance or presentation of the work described in this manuscript. 


\section{PENDAHULUAN}

Pendidikan merupakan usaha sadar dan terencana untuk menciptakan suasana belajar agar peserta didik secara aktif mengembangkan berbagai potensi dirinya untuk memiliki kekuatan spiritual keagamaan, pengendalian diri, kepribadian, kecerdasan, sikap sosial dan keterampilan yang diperlukan dirinya, masyarakat, bangsa dan negara. Dengan adanya pendidikan, manusia mempunyai pengetahuan dan kemampuan dan menjadi modal yang berharga agar bisa tetap hidup di masa sekarang dan yang akan datang. Pendidikan juga sangat penting dalam upaya mengembangkan kualitas sumber daya manusia. Ini sesuai dengan tujuan pendidikan nasional yang tertuang dalam UU No. 20 tahun 2003 bab II pasal 3 tentang Sistem Pendidikan Nasional dinyatakan bahwa: "Pendidikan nasional berfungsi mengembangkan kemampuan dan membentuk watak seperti peradaban bangsa yang bermartabat dalam rangka mencerdaskan kehidupan bangsa, bertujuan untuk berkembangnya potensi peserta didik agar menjadi manusia yang beriman dan bertaqwa kepada Tuhan Yang Maha Esa, berakhlak mulia, sehat, berilmu, cakap, kreatif, mandiri, menjadi warga negara yang demokratis serta bertanggung jawab."

Pelaksanaan pendidikan perlu kerjasama antara pemerintah, berbagai kelompok masyarakat, orangtua dan dewan pendidikan. Pendidikan harus mampu mengembangkan potensi peserta didik, sehingga peserta didik mampu menghadapi dan memecahkan permasalahan kehidupan yang dihadapinya. Banyak mata pelajaran yang diberikan di pendidikan formal, salah satunya adalah matematika. Banyak yang beranggapan bahwa matematika merupakan mata pelajaran yang sulit. Padahal matematika harus dipelajari sebagai sarana untuk memecahkan masalah dalam kehidupan sehari-hari.

Pada kenyataannya memang banyak siswa kurang berminat terhadap matematika. Hal ini akan berdampak pada kurangnya penguasaan terhadap konsep-konsep dalam matematika. Selain pemahaman konsep dalam matematika, penanaman konsep yang benar juga sangat diperlukan dalam proses pembelajaran matematika. Pembelajaran yang baik seharusnya berpusat pada peserta didik. Peserta didik harus aktif, kreatif dan inovatif. Selain itu, peserta didik juga bisa belajar dengan cara dan gaya belajar masing-masing.

Berdasarkan pengamatan di beberapa sekolah, pembelajaran masih berpusat pada guru. Peserta didik masih mengandalkan informasi atau materi ajar dari guru, sehingga apabila ada permasalahannya yang tidak sama dengan apa yang diberikan oleh guru, peserta didik kurang mampu menyelesaikan masalah tersebut. Hal ini terlihat dari data nilai ulangan harian matematika peserta didik yang masih tergolong rendah atau di bawah nilai Kriteria Ketuntasan Minimal (KKM).

Tabel 1. Nilai Rata-Rata Ulangan Harian Matematika di SMP YASDIQ

\begin{tabular}{ccccc}
\hline Mata & \multicolumn{3}{c}{ Rata-Rata Ulangan Harian Ke- } & \multirow{2}{*}{ KKM } \\
\cline { 2 - 4 } Pelajaran & I & II & III & \\
\hline Matematika & 65 & 55 & 65 & 70 \\
\hline
\end{tabular}

Sumber: Data Dokumen dari SMP YASDIQ TA 2015/2016.

Permasalahan di atas dijumpai dalam pembelajaran matematika di SMP YASDIQ. Berdasarkan hasil pengamatan, tingkat pemahaman konsep yang ditunjukkan oleh kemampuan siswa masih rendah. Untuk itu diperlukan solusi dalam pembelajaran yang tepat. Salah satu solusinya melalui penerapan model pembelajaran yang menarik dan tepat yang dapat membangun minat siswa terhadap matematika, sehingga matematika bukan lagi mata pelajaran yang menakutkan, tetapi pelajaran yang menyenangkan. 
Model yang dapat digunakan adalah model pembelajaran mind mapping sebagai kelas eksperimen. Menurut pendapat Tony Buzan, dapat saya simpulkan bahwa mind mapping merupakan suatu cara mencatat yang kreatif, efektif, dan secara harfiah akan memetakan pikiran-pikiran. Dengan menggunakan model pembelajaran mind mapping siswa dapat menghasilkan catatan yang memberikan banyak informasi dari satu halaman. Sehingga daftar informasi yang panjang bisa dialihkan menjadi petakan yang teratur dan mudah diingat yang selaras dengan cara kerja alami otak.

Model lain yang dapat digunakan adalah model pembelajaran kooperatif tipe STAD (Student Teams Achievement Division) sebagai kelas kontrol. Menurut pendapat Ngalimun, dapat saya simpulkan bahwa pembelajaran kooperatif tipe STAD merupakan salah satu model pembelajaran kooperatif dengan pengarahan, diskusi, kuis, dan skor perkembangan tiap siswa atau kelompok, dan pemberian reward. Pembelajaran kooperatif tipe STAD dicirikan oleh suatu struktur tugas, tujuan, dan penghargaan kooperatif. Siswa bekerja sama dalam situasi dan semangat pembelajaran kooperatif.

\section{METODE}

Penelitian ini dilaksanakan di Sekolah Menengah Pertama (SMP) YASDIQ yang merupakan salah satu Sekolah Menengah Pertama berciri khas keagamaan dan berlandaskan kepada nilai-nilai keislaman dan karakter budaya bangsa yang luhur. Metode dalam penelitian ini adalah metode eksperimen, dengan variabel penelitian adalah model pembelajaran mind mapping sebagai variabel bebas dan hasil belajar matematika sebagai variabel terikat. Peneliti menggunakan desain posttest only control group design. Adapun desain penelitiannya digambarkan sebagai berikut.

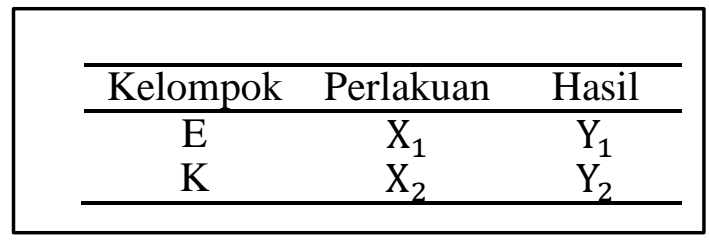

Gambar 1. Desain Penelitian

Keterangan:

$\mathrm{E} \quad$ : Kelompok kelas eksperimen

$\mathrm{K}$ : Kelompok kelas kontrol

$\mathrm{X}_{1}$ : Perlakuan untuk kelas eksperimen dengan menggunakan model pembelajaran mind mapping

$\mathrm{X}_{2}$ : Perlakuan untuk kelas kontrol dengan menggunakan model pembelajaran kooperatif tipe STAD

$\mathrm{Y}_{1}$ : Skor hasil posttest dengan soal yang sama pada kelas eksperimen

$\mathrm{Y}_{2}$ : Skor hasil posttest dengan soal yang sama pada kelas kontrol

Populasi target dalam penelitian ini adalah seluruh siswa di SMP YASDIQ semester genap tahun ajaran 2015/2016. Populasi terjangkau dalam penelitian ini adalah seluruh siswa kelas VII di SMP YASDIQ. Sampel dalam penelitian ini diambil 40 siswa sebagai sampel penelitian, kemudian dibagi menjadi dua kelas.

Sebanyak 20 orang siswa di kelas VII.B sebagai kelas eksperimen dan 20 orang siswa di kelas VII.C sebagai kelas kontrol. Teknik pengambilan sampel pada penelitian ini adalah teknik simple random sampling. Teknik ini digunakan untuk menentukan kelas penelitian. Sumber data dalam penelitian ini, untuk model pembelajaran bersumber dari dokumen kepustakaan (dokumen yang berhubungan dengan masalah yang dibahas dalam penelitian). Adapun untuk hasil belajar matematika bersumber dari siswa yang menjadi 
sampel penelitian pada saat ulangan harian untuk pokok bahasan bangun datar. Teknik pengumpulan data untuk hasil belajar matematika siswa melalui tes hasil belajar matematika dengan pokok bahasan bangun datar.

Hasil belajar matematika adalah kemampuan menggunakan simbol-simbol setelah melakukan suatu kegiatan belajar untuk mendapatkan pengetahuan, wawasan, dan perubahan yang lebih baik. Secara operasional, hasil belajar matematika adalah skor kemampuan menggunakan simbol-simbol setelah melakukan suatu kegiatan belajar untuk mendapatkan pengetahuan, wawasan, dan perubahan yang lebih baik, dimana hasil belajar tersebut diambil melalui tes pilihan ganda sebanyak 25 butir soal yang valid semua. Dengan menggunakan instrumen tes yang butir-butir soalnya terlebih dahulu diuji di kelas lain yang tidak dijadikan sampel penelitian untuk menguji validitasnya.

Ujicoba instrumen dilakukan di kelas lain yang tidak dijadikan kelompok sampel. Pedoman penskoran untuk memperoleh data hasil belajar matematika yaitu jawaban benar diberi skor 1 dan jawaban salah diberi skor 0. Karakteristik instrumen: ranah kognitif C1, C2, dan C3. Semua butir soal dinyatakan valid dengan skor korelasi diantara 0,45 s.d. 0,90 ; indeks daya pembeda soal berada pada rentang 0,11 s.d. 0,92 yang masuk kategori jelek, cukup, baik, dan sangat baik; tingkat kesukaran semua butir soal masuk kategori mudah, sedang, dan sukar dengan rentang indeks kesukaran soal berada pada 0,15 s.d. 0,90; dan skor reliabilitas 0,96 .

\section{HASIL}

Subjek penelitian ini adalah siswa kelas VII di SMP YASDIQ dengan sampel yang diambil adalah kelas VII.B sebanyak 20 orang siswa sebagai kelas eksperimen dan kelas VII.C sebanyak 20 orang siswa sebagai kelas kontrol. Responden berada pada rentang usia antara 12 s.d. 13 tahun dengan kemampuan kognitif yang heterogen, yang mana tidak ada kelas unggulan untuk dilaksanakan pembelajaran.

Penelitian ini fokus ke treatment berupa penerapan model pembelajaran mind mapping untuk kelas eksperimen dan model pembelajran kooperatif tipe STAD untuk kelas kontrol. Perlakuan diberikan dengan sama banyak untuk durasinya yaitu masing-masing enam kali tatap muka. Kemudian pada bagian akhir, yaitu tatap muka ketujuh dilakukan posttest untuk mengukur hasil belajar matematika siswa. Setelah dilakukan serangkaian kegiatan perlakuan di dua kelas tersebut, diperoleh data hasil penelitian. Data pada penelitian ini adalah data yang terkumpul dari tes yang telah diberikan kepada siswa SMP YASDIQ, berupa data hasil tes hasil belajar matematika siswa yang dilaksanakan sesudah proses pembelajaran. Hasil perhitungan untuk statistik deskriptif dalam penelitian ini direkap dan ditampilkan pada tabel 2. 
Tabel 2. Rekapitulasi Hasil Perhitungan Deskripsi Data Hasil Belajar Matematika

\begin{tabular}{ccc}
\hline Deskripsi Data & Kelas Eksperimen & Kelas Kontrol \\
\hline Nilai Terendah & 68 & 64 \\
Nilai Tertinggi & 92 & 88 \\
Mean & 80,75 & 74,75 \\
Median & 81,25 & 74,93 \\
Modus & 88,33 & 75,5 \\
Varians & 55,99 & 31,25 \\
Simpangan Baku & 7,48 & 5,6 \\
\hline
\end{tabular}

Sumber: Diolah dari data penelitian, 2016.

Setelah hasil penelitian dipaparkan secara deskriptif, dilanjutkan dengan pengujian hipotesis penelitian yaitu dengan uji beda rerata. Namun, sebelum dilakukan pengujian hipotesis perlu dilakukan ujin persyaratan analisis terlebih dahulu terhadap data hasil penelitian. Uji prasyarat analisis yang perlu dilakukan adalah uji normalitas data dan uji homogenitas varians. Dalam penelitian ini, uji normalitas data dilakukan dengan uji Liliefors dan uji homogenitas varians dilakukan dengan uji Fisher.

Berdasarkan pada hasil perhitungan uji normalitas data, diperoleh simpulan bahwa dua kelompok data dalam penelitian ini berdistribusi normal, yaitu data kelas eksperimen dan data kelas kontrol dinyatakan berasal dari populasi yang berdistribusi normal. Hal ini ditunjukkan dengan nilai $\mathrm{L}_{\text {hitung }}<\mathrm{L}_{\text {tabel }}$ untuk dua kelompok data hasil penelitian. Kemudian berdasarkan pada perhitungan uji homogenitas varians, diperoleh simpulan bahwa dua kelompok data mempunya varians yang homogen. Hal ini dibuktikan dengan nilai $F_{\text {hitung }}<\mathrm{F}_{\text {tabel }}$ untuk data hasil penelitian. Secara rinci, rekapitulasi hasil perhitungan uji normalitas data untuk kelas eksperimen ditampilkan pada tabel 3 dan rekapitulasi hasil perhitungan uji normalitas data untuk kelas kontrol ditampilkan pada tabel 4. Adapun rekapitulasi hasil perhitungan uji homogenitas varians ditampilkan pada tabel 5.

Setelah uji persyaratan analisis data selesai dilakukan, selanjutnya dilakukan uji hipotesis penelitian yang dilakukan dengan uji $\boldsymbol{t}$. Berdasarkan pada pengujian hipotesis penelitian, diperoleh simpulan bahwa $t_{\text {hitung }}>t_{\text {tabel }}(3,15>1,70)$ maka $\mathrm{H}_{0}$ ditolak dan $\mathrm{H}_{1}$ diterima pada $\alpha=0,05$. Dengan demikian rata-rata hasil belajar matematika kelompok eksperimen lebih tinggi secara signifikan daripada rata-rata hasil belajar matematika kelompok kontrol. Atau dengan kata lain, hasil belajar matematika kelompok siswa yang diberi perlakuan berupa pembelajaran dengan model mind mapping lebih tinggi secara signifikan daripada ratarata hasil belajar matematika kelompok siswa yang diberi perlakuan berupa model pembelajaran kooperatif tipe $S T A D$. Hal ini secara tegas dapat dinyatakan bahwa penerapan model pembelajaran mind mapping berpengaruh signifikan terhadap hasil belajar matematika. Rekapitulasi hasil perhitungan uji hipotesis penelitian ditampilkan pada tabel 6. 
Tabel 3. Uji Normalitas Data Kelas Eksperimen



Sumber: Data primer yang diolah

Tabel 4. Uji Normalitas Data Kelas Kontrol

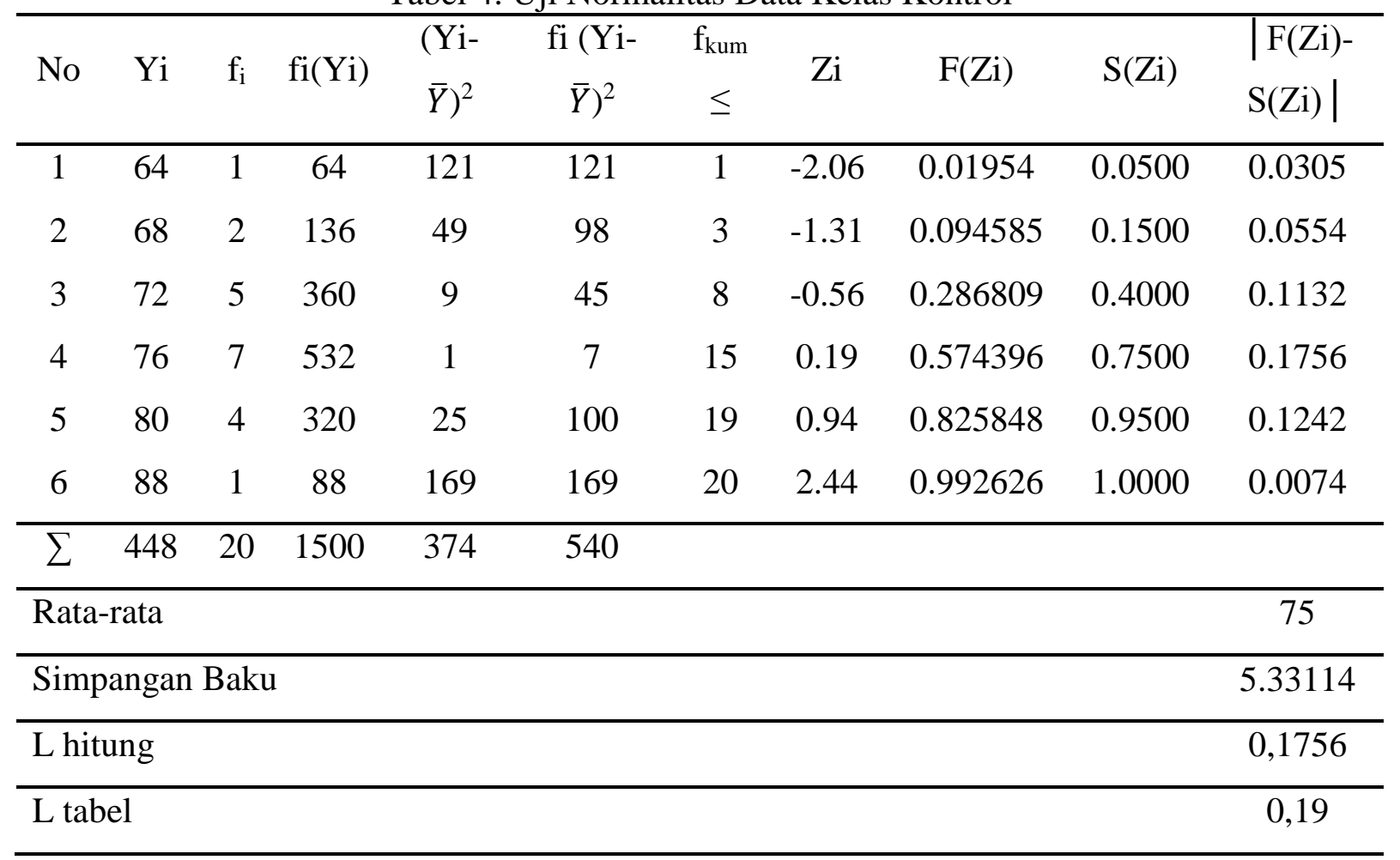

Sumber: Data primer yang diolah 
Tabel 5. Uji Homogenitas Varians

\begin{tabular}{cccccc}
\hline Kelompok & $\begin{array}{c}\text { Jumlah } \\
\text { Sampel }\end{array}$ & $\begin{array}{c}\text { Varians } \\
\left(\mathrm{s}^{2}\right)\end{array}$ & $\mathrm{F}_{\text {hitung }}$ & $\mathrm{F}_{\text {tabel }}$ & Simpulan \\
\hline $\begin{array}{c}\text { Eksperimen } \\
\text { Kontrol }\end{array}$ & 20 & $\begin{array}{c}181.05 \\
332,63\end{array}$ & 1,837 & 2,168 & Terima $\mathrm{H}_{0}$ \\
\hline
\end{tabular}

Sumber: Data primer yang diolah

Tabel 6. Uji Beda Rerata

\begin{tabular}{cccccc}
\hline Kelompok & Sampel & Mean & $t_{\text {hitung }}$ & $t_{\text {tabel }}$ & Simpulan \\
\cline { 1 - 3 } Eksperimen & 20 & 20,05 & & & \\
\cline { 1 - 3 } Kontrol & 20 & 18,35 & & & Tolak $\mathrm{H}_{0}$ \\
\hline
\end{tabular}

Sumber: Data primer yang diolah

\section{PEMBAHASAN}

Belajar adalah aktivitas terencana yang terjadi pada semua orang dan berlangsung sepanjang hidup yang didapatkan berkat pengalaman dan latihan, agar tingkah laku seseorang mengalami perubahan yang lebih baik. Kegiatan belajar bisa berlangsung jika ada proses belajar antara guru dan siswa. Dalam proses belajar tersebut guru juga membutuhkan metode pembelajaran. Model pembelajaran yang digunakan guru harus sesuai dengan kondisi kelas yang sedang diajar. Banyak sekali model dan metode pembelajaran inovatif, diantaranya yaitu model pembelajaran mind mapping. Dalam menentukan tingkat keberhasilan pembelajaran adalah menguasai suatu konsep. Dengan menguasai konsep seseorang mampu memahami makna secara ilmiah, baik konsep secara teori maupun penerapannya dalam kehidupan sehari-hari. Untuk itu diperlukannya metode yang sesuai untuk mengembangkan penguasaan konsep siswa.

Lestari (2013: 118) menyatakan "Hasil belajar merupakan akibat dari proses belajar seseorang". Hasil belajar terkait dengan perubahan pada diri orang yang belajar. Bentuk perubahan sebagai hasil dari belajar berupa perubahan pengetahuan, pemahaman, sikap dan tingkah laku, keterampilan dan kecakapan. Menurut Dimyati dan Mudjiono (2013: 20), "Hasil belajar merupakan suatu puncak proses belajar". Hasil belajar tersebut terjadi terutama berkat evaluasi guru. Hasil belajar dapat berupa dampak pengajaran dan dampak pengiring. Kedua dampak tersebut bermanfaat bagi guru dan siswa. Dengan demikian, hasil belajar adalah kemampuan yang dimiliki siswa setelah menerima kegiatan belajarnya yang mencakup aspek kognitif, afektif, dan psikomotorik. Berdasarkan hasil penelitian ini, hasil belajar matematika siswa dipengaruhi oleh penerapan model pembelajaran.

Penggunaan model pembelajaran mind mapping memiliki pengaruh terhadap hasil belajar matematika siswa lebih tinggi dari model pembelajaran STAD. Dari deskripsi data yang diperoleh bahwa hasil belajar 
matematika siswa yang diajar menggunakan model pembelajaran mind mapping dari 20 siswa dengan nilai tertinggi 92, dan terendah 68 memiliki rata - rata nilai 80,75. Sedangkan hasil belajar matematika siswa yang diajar menggunakan model pembelajaran STAD dari 20 siswa dengan nilai tertinggi 88 dan terendah 64 memiliki nilai rata - rata 74,75. Dari hasil perhitungan penelitian ini dapat disimpulkan bahwa nilai rata - rata hasil belajar siswa kelas eksperimen yang diajar dengan menggunakan model pembelajaran mind mapping lebih tinggi daripada nilai hasil belajar siswa kelas kontrol yang diajar menggunakan model pembelajaran $S T A D$. Hal tersebut disebabkan karena dengan menggunakan model pembelajaran mind mapping, siswa dapat menghasilkan catatan yang memberikan banyak informasi dari satu halaman. Sehingga daftar informasi yang panjang bisa dialihkan menjadi petakan yang teratur dan mudah diingat yang selaras dengan cara kerja alami otak.

Menurut Buzan (2008: 4), "Mind mapping adalah cara mengembangkan kegiatan berpikir ke segala arah, menangkap berbagai pikiran dalam berbagai sudut. Mind mapping yang sering kita sebut dengan peta konsep adalah alat berpikir organisasional yang sangat hebat yang juga merupakan cara termudah untuk menempatkan informasi ke dalam otak dan mengambil informasi itu ketika dibutuhkan". Kelebihan model pembelajaran mind mapping diantaranya meningkatkan kreativitas dan aktivitas individu maupun kelompok, memudahkan otak memahami dan menyerap informasi dengan cepat, dan dapat mengakomodasi berbagai sudut pandang terhadaap suatu informasi. Hal ini sejalan dengan Dwijayanti (2007) yang menyatakan bahwa, "Penerapan metode pembelajaran mind mapping telah memberikan pengalaman baru bagi siswa maupun guru dan memberikan beberapa manfaat bagi guru dan siswa". Setyawati (2011), dalam hasil penelitiannya menyimpulkan bahwa kemampuan membaca dini anak meningkat setelah dilakukan penerapan teknik membaca melalui mind mapping.

Model mind mapping memiliki peranan penting dalam pemahaman dan penguasaan konsep siswa, siswa mudah mengingat materi yang diajarkan bukan dengan cara menghafal. Melalui model pembelajaran mind mapping, siswa juga dalam menyelesaikan permasalahan dan dapat berpikir aktif tanpa harus selalu runtut sama seperti cara atau langkah-langkah penyelesaian yang diberikan oleh guru. Model pembelajaran mind mapping merupakan model yang menggunakan peta konsep sebagai alat dalam penyampaian materi pembelajaran yang bertujuan mendorong siswa untuk belajar berpikir kritis dengan jalan memecahkan permasalahan - permasalahan. Model pembelajaran mind mapping dapat membantu dalam berpikir kritis. Siswa diarahkan untuk mengidentifikasi masalah, mencari alternatif pemecahan masalah, dan menemukan cara pemecahan masalah yang paling efektif, serta melakukan tindak lanjut.

Pada waktu penulis menerapkan model pembelajaran mind mapping, siswa meresponnya dengan sangat baik. Hal ini karena peneliti menghadirkan peta pikiran yang berhubungan dengan materi yang dipelajari. Penulis juga membagi siswa dalam kelompok - kelompok yang heterogen. Hal ini dapat membantu siswa untuk bekerja sama dan saling melengkapi, sehingga materi yang dipelajari benar - benar dimengerti dan diterima oleh siswa. Nilai rata - rata hasil belajar siswa yang diajar dengan menggunakan model pembelajaran STAD lebih rendah karena ini lebih banyak diberikan melalui ceramah, akan sulit mengembangkan kemampuan siswa dalam hal kemampuan berpikir kritis. Walaupun model pembelajaran STAD ini sangat efektif jika materi pelajaran yang harus dikuasai siswa cukup luas sementara waktu yang dimiliki siswa untuk belajar terbatas tetapi model pembelajaran ini hanya mungkin dapat dilakukan terhadap siswa yang memiliki kemampuan menyimak dan mendengar. Student Team Achievement Divisions (STAD) adalah salah satu tipe pembelajaran kooperatif yang paling sederhana. Siswa ditempatkan dalam tim belajar beranggotakan empat orang yang merupakan campuran menurut tingkat kinerjanya, jenis kelamin dan suku. Guru menyajikan pelajaran kemudian siswa bekerja dalam tim untuk memastikan bahwa seluruh anggota tim telah menguasai pelajaran tersebut.

Hakikatnya, setiap siswa mengharapkan kegiatanbelajarnya mudah dan menyenangkan untuk smeua mata pelajaran. Pemilihan metode atau model pembelajaran yang tepat sesuai dengankarakteristik siswa di 
dalam kelas sangat menentukan keberhasilan belajar siswa. Hal ini sesuai dengan pendapat Marliani dan Hakim (2015), "Dalam proses mengajar, seorang pendidik tidak harus terpaku dengan menggunakan satu metode mengajar, akan tetapi harus menggunakan beberapa metode mengajar yang digunakan secara bervariasi agar pengajaran tidak membosankan." Alangkah jauh lebih baik manakala guru dapat menarik perhatian peserta didik. Meski penggunaan metode bervariasi tidak akan menguntungkan proses interaksi belajar mengajar bila penggunaan metode tidak tepat dengan situasi pengajaran yang mendukungnya.

Penelitan yang dilakukan oleh Siti Iva Mufida yang berjudul: "Pengaruh Metode Mind Mapping dan Jenis Kelamin terhadap Hasil Belajar Siswa Kelas VII MTsN Karangrejo Tulungagung Pajar Bulan pada pelajaran matematika dengan pokok bahasan Bangun Datar", Program Studi Tadris Matematika Jurusan Tarbiyah, Sekolah Tinggi Agama Islam Negeri Tulungagung, 2013. Penelitian ini bertujuan untuk mengetahui Pengaruh Penggunaan Metode Mind Mapping dan Jenis Kelamin terhadap Hasil Belajar Siswa MTsN Karangrejo Tulungagung. Nilai rata - rata hasil belajar siswa $X_{1}$ (eksperimen) yaitu sebesar 87,56 dan nilai rata- rata $X_{2}$ (kontrol) yaitu adalah 83,17, sehingga rentang atau selisih dari nilai keduanya adalah 4,39. Hal tersebut menunjukan bahwa dengan penerapan metode pembelajaran mind mapping dalam pembelajaran matematika dapat meningkatkan hasil belajar siswa.

Sedangkan penelitian yang dilakukan penulis pada siswa kelas VII di SMP YASDIQ, menunjukan adanya pengaruh model pembelajaran mind mapping terhadap hasil belajar matematika. Dari hasil perhitungan uji t di peroleh nilai $t_{\text {hitung }}$ sebesar 3,15 dan $t_{\text {tabel }}$ adalah 1,70 karena $t_{\text {hitung }}>t_{\text {tabel }}$ yaitu $3,15>1,70$, maka $H_{1}$ diterima yaitu terdapat pengaruh model pembelajaran mind mapping terhadap hasil belajar matematika. Hasil pengujian ini telah membuktikan kebenaran dari hipotesis. Oleh karena itu dapat dikemukakan bahwa penggunaan model pembelajaran mind mapping pada pengajaran materi bangun datar berpengaruh terhadap hasil belajar matematika siswa di SMP YASDIQ.

\section{SIMPULAN}

Berdasarkan hasil penelitian yang diperoleh dengan menggunakan uji $t$, peneliti dapat menyimpulkan bahwa ada pengaruh model pembelajaran mind mapping terhadap hasil belajar matematika siswa dengan pembahasan bangun datar, sehingga dengan menggunakan model pembelajaran mind mapping, rata-rata hasil belajar matematika lebih tinggi daripada penggunaan model pembelajaran STAD di kelas VII SMP YASDIQ tahun pelajaran 2015/2016. Dengan demikian pemberian model pembelajaran mind mapping mempunyai pengaruh dalam meningkatkan hasil belajar matematika siswa SMP YASDIQ.

\section{DAFTAR RUJUKAN}

Buzan, T. (2008). Buku Pintar Mind Map. Jakarta: Gramedia Pustaka Utama.

Dimyati \& Mudjiono. (2013). Belajar dan Pembelajaran. Jakarta: Rineka Cipta.

Dwijayanti, E. (2007). Penerapan Strategi Pembelajaran Mind Mapping untuk Meningkatkan Prestasi Belajar Siswa Kelas IV SD Mata Pelajaran IPS Materi Pokok Perkembangan Teknologi Produksi, Komunikasi, dan Transportasi di SD 1 Lidah Kulon Surabaya. Skripsi. Universitas Negeri Surabaya. 
Lestari, I. (2013). Pengaruh Waktu Belajar dan Minat Belajar terhadap Hasil Belajar Matematika. Vol 3. No 2. Jurnal ilmiah Pendidikan Matematika dan Ilmu Pengetahuan Alam.

Marliani, N., \& Hakim, A. R. (2015). Pengaruh Metode Belajar dan Kecemasan Diri terhadap Hasil Belajar Matematika Peserta Didik. Jakarta: Jurnal Kajian Pendidikan Matematika. 1(1): 136-150.

Mufida, S. I. (2013). Pengaruh Metode Mind Mapping dan Jenis Kelamin terhadap Hasil Belajar Siswa Kelas VII MTsN Karangrejo Tulungagung Pajar Bulanpada pelajaran matematika dengan pokok bahasan Bangun Datar. Skripsi. Sekolah Tinggi Agama Islam Negeri Tulungagung.

Sanjaya, W. (2008). Strategi Pembelajaran Berorientasi Standar Proses Pendidikan. Jakarta: Kencana Prenada Media Group.

Setyawati, L. (2011). Penerapan Teknik Membaca Melalui Mind Mapping dalam Pembelajaran Membaca Dini pada Usia Dini. Skripsi. Universitas Negeri Makasar.

Slameto, (2010). Belajar dan Faktor - Faktor yang Mempengaruhinya. Jakarta: Rineka Cipta.

Slavin, R. E. (2010). Cooperative Learning. Diterjemahkan oleh: Narulita Yusron. Bandung: Nusa Media.

Suhendri, H. (2011). Pengaruh Kecerdasan Matematika Logis dan Kemandirian Belajar terhadap Hasil Belajar Matematika. Jurnal Formatif, 1 (1) : 29-39. 